\title{
The second North American fossil horntail wood-wasp (Hymenoptera: Siricidae), from the early Eocene Green River Formation
}

\author{
S. BRUCE ARCHIBALD ${ }^{1}$, ARVID AASE ${ }^{2} \& \mathrm{ANDRÉ}^{\mathrm{N} E L^{3}}$ \\ ${ }^{\prime}$ Department of Biological Sciences, Simon Fraser University, 8888 University Drive, Burnaby, British Columbia, V5A 1S6, Canada; \\ and Museum of Comparative Zoology, 26 Oxford Street, Cambridge, Massachusetts, 02138, United States of America; and Royal Brit- \\ ish Columbia Museum, 65 Belleville Street, Victoria, British Columbia, V8W 9W2, Canada. \\ "s sba48@sfu.ca; 1 https://orcid.org/0000-0002-4397-2497 \\ ${ }^{2}$ Fossil Butte National Monument, 864 Chicken Creek Road, Kemmerer, WY 83101, Wyoming, USA. \\ "=arvid_aase@nps.gov; ㄴ. https://orcid.org/0000-0002-2433-9004 \\ ${ }^{3} I n s t i t u t$ de Systématique, Évolution, Biodiversité (ISYEB) Muséum national d'Histoire naturelle, CNRS, Sorbonne Université, EPHE, \\ Université des Antilles, CP50, 57 rue Cuvier 75005 Paris, France. \\ झ"anel@mnhn.fr; 10 https://orcid.org/0000-0002-4241-7651
}

\begin{abstract}
Eoteredon lacoi gen. et sp. nov., is described from the early Eocene Green River Formation in Wyoming, the second fossil siricid genus and species described from North America. We propose Eoteredon as sister to the genus Teredon, whose sole species is one of the rarest of extant Siricidae. The majority of siricids today inhabit temperate Northern Hemisphere forests; Teredon cubensis, however, is one of its few species that live in megathermal tropical lowlands. The Eocene forest that Eoteredon inhabited had a mesothermal to megathermal climate. We place Eoteredon in the context of broad Cenozoic climate change.
\end{abstract}

Key words: Insecta, 'Symphyta', Teredon, paleobiogeography

\section{Introduction}

Horntail wood-wasps (Siricidae) consist of ten extant genera (Schiff et al. 2012) that are mainly distributed in Holarctic forests, from the northern tree line through mid-latitudes, with few outside of this range. Most Mesozoic taxa ascribed to the family require revision of their higher level systematics (see Archibald \& Rasnitsyn 2016), and the few fossils known of its crown group are mainly from the Cenozoic of Eurasia (e.g., Nel 1988, 1991; Wedmann 1998; Rajchel \& Uchman 1998; Riou 1999; Wedmann et al. 2014). Only two are known from the New World: the Early Cretaceous Cratosirex sennlaubi Jouault et al. 2020 from Brazil, and the Ypresian (early Eocene) Ypresiosirex orthosemos Archibald \& Rasnitsyn 2016 from British Columbia, Canada. Here we describe the second North American fossil crown group siricid, from the Ypresian Green River Formation of Wyoming.

\section{Geologic Setting}

The Green River Formation is comprised of lacustrine sediments deposited in three basins by intermittently interconnected lakes over a span of eight million years (Smith et al. 2008 and others cited therein). Fossil Basin, the smallest of the three, formed behind the leading edge of the Wyoming thrust in what is now southwest Wyoming, USA (Fig. 1). Lacustrine deposits in Fossil Basin are approximately 120 meters thick (Buchheim et al. 2011) (Fig. 2). Over a hundred air-fall ashes are documented but only the $51.98 \pm 0.35 \mathrm{Ma}$ (Smith et al. 2008; Smith et al. 2010; Smith \& Carroll 2015) K-spar Tuff has been dated. The tuff is six meters above the 18 -inch Layer (named for its average thickness) where the wasp was found. Although deposition rates are unknown, this appears to be well within the Early Eocene Climatic Optimum (EECO) in the latter half of the Ypresian (e.g., Inglis et al. 2020; Luciani et al. 2020). 


\section{Material and methods}

An imperfect split of the laminated limestone containing the specimen caused portions of it to adhere to the counterpart. The specimen was prepared by Mike Eklund using silicon wafer probes under a Leica MZ16F microscope. During preparation, it was determined that further removal of obscuring matrix would cause irreparable damage to the specimen and so portions of limestone were thinned rather than removed. Thinned matrix then becomes translucent when wetted with ethyl alcohol, revealing hidden morphology. Photography was done by Harold Ikerd at the United States Department of Agriculture's Pollinating Insect-Biology, Management, Systematics Research (Bee Lab) in Logan, Utah, USA using a Keyence VHX-5000 microscope and camera system. The specimen was photographed both dry and wetted. Line drawings are composites done from dry, wet, part and counterpart images.

We follow the morphological terminology and systematics of Schiff et al. (2012), except that we follow Rasnitsyn $(1968,1969)$, Wedmann et al. (2014), and Archibald \& Rasnitsyn (2016) in recognizing the Siricinae as the sole defined subfamily of Siricidae sensu stricto, assuming that revision of Mesozoic taxa will establish others. Contrary character states of compared taxa are provided in brackets. Mean annual temperature (MAT) categories are sensu Wolfe (1975): microthermal, $\leq 13{ }^{\circ} \mathrm{C}$; mesothermal, $>13{ }^{\circ} \mathrm{C},<20^{\circ} \mathrm{C}$; megathermal, $\geq 20^{\circ} \mathrm{C}$.

\section{Systematic paleontology}

\section{Order Hymenoptera Linnaeus 1758}

\section{Family Siricidae Billberg 1820}

\section{Genus Eoteredon gen. nov.}

Type species. Eoteredon lacoi sp. nov.

Etymology. The genus name is derived from Eos, the Latin name for the Greek goddess of the dawn, and that of the extant genus Teredon Norton 1869. Gender, masculine.

Diagnosis. Female characters only. Closest to Teredon (see discussion), but easily separated from Teredon females by any of the following: broad metathoracic femur, much broader than tibia; forewing character states: cell 1R width about a third length [about a fifth]; cell 3R1 distinctly closed (R1 joins Rs) [open]; 1r-rs distinct [very short or R1, Rs meet at pterostigma]; Rs and M only touch without distinct Rs $+\mathrm{M}$ [distinct Rs $+\mathrm{M}$ ].

\section{Eoteredon lacoi sp. nov.}

(Figs 3, 4)

Material. Holotype FOBU13582 (part and counterpart of a nearly complete female) (Fig. 3). Housed in the collections of Fossil Butte National Monument, Kemmerer, Wyoming.

Etymology. The specific epithet is formed from the surname of Greg Laco, who donated the holotype to Fossil Butte National Monument, recognizing his contribution.

Diagnosis. As for the genus.

Type locality and horizon. The type and only specimen was found in the 18-inch Layer of the Fossil Butte Member of the Green River Formation in Fossil Basin, approximately six meters below the K-spar Tuff dated at $51.98 \pm 0.35 \mathrm{Ma}$. The Smith Hollow type locality is 11 miles west of downtown Kemmerer, Wyoming, USA.

Description. Female, preserved in ventral aspect, except head in frontal aspect. Head poorly preserved, 4.5 $\mathrm{mm}$ long, $3.5 \mathrm{~mm}$ wide, with compound eyes, mandibles poorly visible; ocelli, antenna, antennal sockets not discernible; thorax $8.7 \mathrm{~mm}$ long, $5.5 \mathrm{~mm}$ wide; only parts of metathoracic legs preserved, poorly: femur $2.2 \mathrm{~mm}$ long and $1.0 \mathrm{~mm}$ wide, 3.5 as broad as metatibia; metatibia ca. $3.8 \mathrm{~mm}$ long as preserved, $0.3 \mathrm{~mm}$ wide; fragments of 

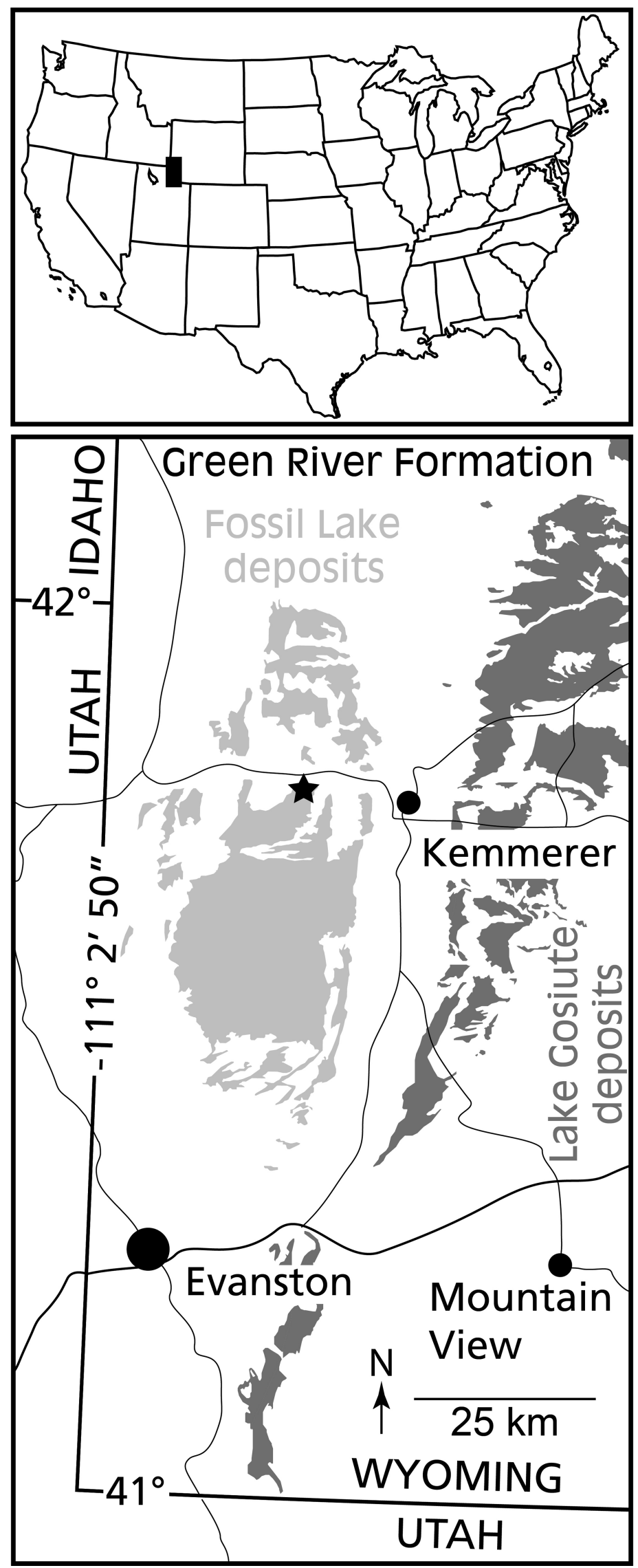

FIGURE 1. Fossil Lake occupied southwest Wyoming, USA, extending westward into Idaho and Utah. After lithification the laminated limestones were eroded exposing the fossil bearing layers. The star marks where the siricid wasp was found about 8.8 $\mathrm{km}$ from the eastern shore. 


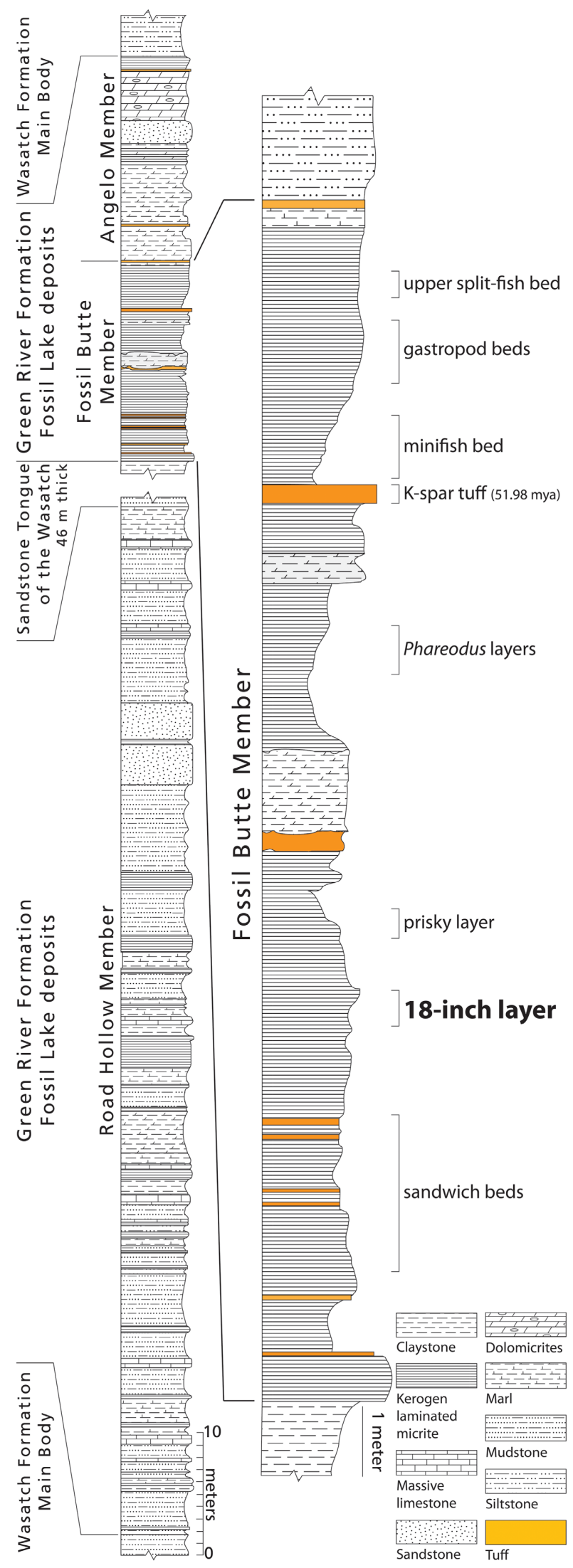

FIGURE 2. Fossil bearing layers are primarily laminated limestones interspersed with volcanic tuffs. The K-spar Tuff is the thickest, making it an easily recognized marker bed. Five layers produce prolific fossils, two below and three above the K-spar Tuff. The siricid wasp was found in the 18-inch Layer about six meters below the K-spar Tuff. Stratigraphic column modified from Buchheim et al (2011). 
metabasitarsomere possibly present. Forewing $17.5 \mathrm{~mm}$ long, $5.0 \mathrm{~mm}$ wide, with apex poorly preserved; $2 \mathrm{r}-\mathrm{m}$ present, joins cell 2M; cell 1Rs2 clearly longer than wide; cell 1R1 rather broad, only 2.8 times as long as broad; cell 2R1 about 0.7 times as long as cell 3R1; 2r-rs joins stigma in its distal half; stigma gradually attenuated evenly distal to junction with 2r-rs; Cul absent; $1 \mathrm{cu}-\mathrm{a}$ joining $\mathrm{Cu}$ midway between $1 \mathrm{~m}-\mathrm{cu}, \mathrm{M}$; Sc faint, present in basal third of wing; 2A extending along posterior edge of wing about 0.5 times cell $1 \mathrm{~A}$ length; $3 \mathrm{~A}$ possibly distorted (see text). Hind wing ca. $11.3 \mathrm{~mm}$ long; anal cell presumed open (see below); hamuli not discernible; 1r-m clearly shorter than $\mathrm{M}$; 1r-m at basal third of cell 1M; M markedly curved; abdomen $16.3 \mathrm{~mm}$ long, $7.0 \mathrm{~mm}$ wide, tergites not discernible (preserved in ventral aspect); distinct but incomplete ovipositor, preserved portion $8.8 \mathrm{~mm}$ long, extending 2.2 $\mathrm{mm}$ from abdomen; annuli not discernible.

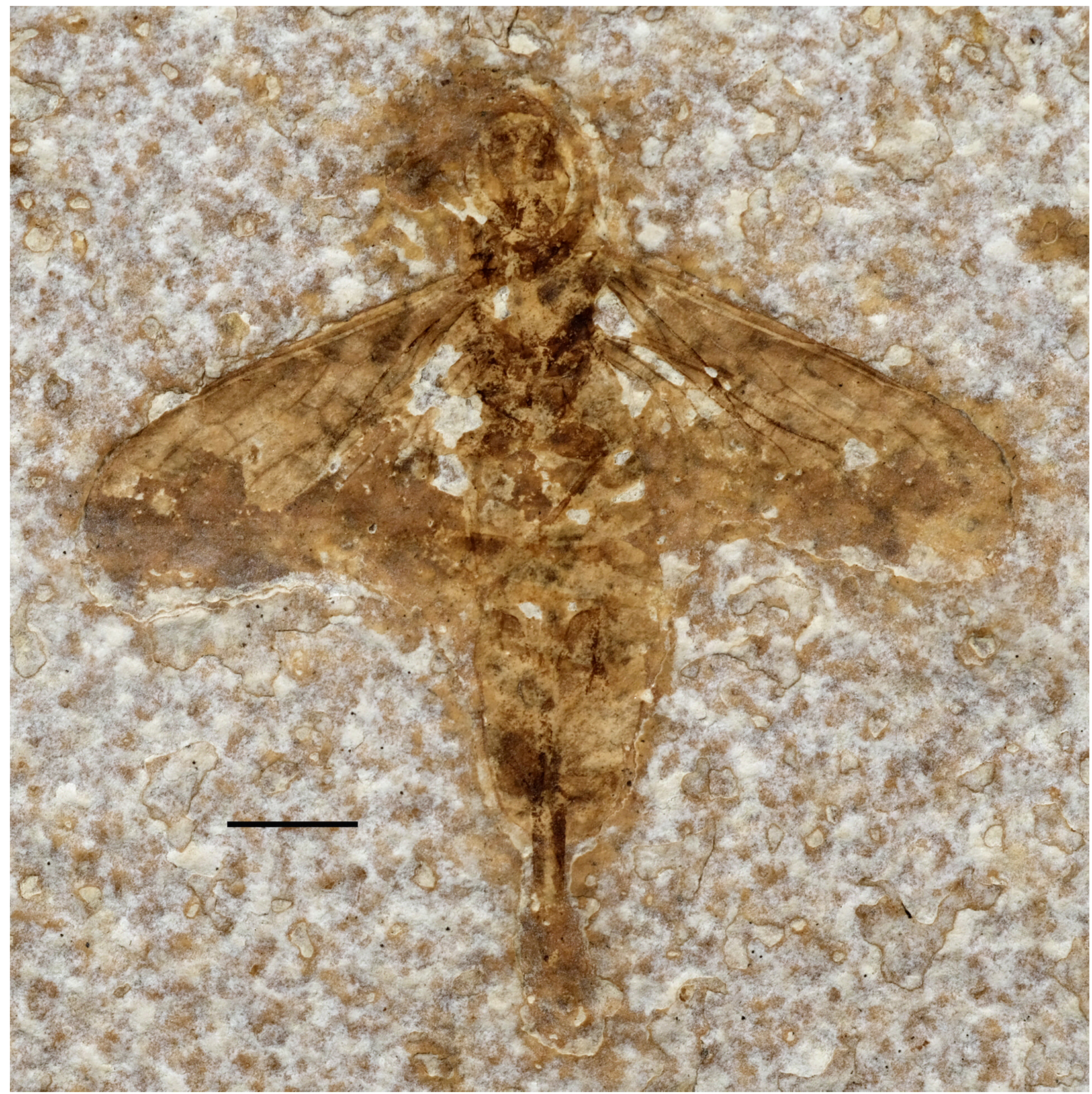

FIGURE 3. Eoteredon lacoi gen. et sp. nov., holotype in ventral aspect, photographed dry. Scale bar $=5 \mathrm{~mm}$.

\section{Discussion}

Teredon has one rare species, T. cubensis (Cresson 1865). Its male and female differ to such a degree that they had originally been considered two species (see Schiff et al. 2012). The most distinct character states of Teredon of both sexes are their flattened, widened metatarsomere 1 and antennae with fewer than 9 flagellomeres. Neither can be assessed on the sole specimen of $E$. lacoi by preservation. 
Although poorly preserved, the compound eye of Eoteredon gen. nov. seems to be rather narrow compared to its height, as in females of Teredon cubensis (Schiff et al. 2012: fig. C34.4).

The forewing venation of Eoteredon gen. nov. is very similar to that of Teredon. According to Schiff et al. (2012), Teredon wings are distinct from those of other Siricidae by a combination of 2r-m present and 1cu-a joining $\mathrm{Cu}$ midway between $\mathrm{M}$ and $1 \mathrm{~m}$-cu in the forewing, and the hind wing with $1 \mathrm{r}-\mathrm{m}$ shorter than $\mathrm{M}$ and $\mathrm{M}$ markedly curved. All of these are shared by Eoteredon gen. nov. Further, in the forewing of both, the apex is acutely and angularly rounded, $2 \mathrm{r}-\mathrm{m}$ is basal to $2 \mathrm{r}-\mathrm{rs}$ and joins cells $2 \mathrm{R} 1$ and $2 \mathrm{M}$; cell $1 \mathrm{Rs} 2$ is clearly wider than long; it is without vein $\mathrm{Cu} 1$; and $1 \mathrm{cu}-\mathrm{a}$ joins $\mathrm{Cu}$ about midway between $1 \mathrm{~m}-\mathrm{cu}$ and $\mathrm{M}$.

The forewing of Eoteredon gen. nov. differs as in the diagnosis (above) and 2r-rs appears to join the stigma more distally than in Teredon, but this is indistinct as the region is poorly preserved. Some details of 2A and 3A cited by Schiff et al. (2012) appear not clearly discernable by preservation in Eoteredon gen. nov. What we interpret as portions of $3 \mathrm{~A}$ in both the left and right forewings (see Fig. 4) appear to be unusually curved parallel to $2 \mathrm{~A}$, but this might be due to partial crumpling of the posterior forewing bases; future specimens are needed to confirm this.

We believe that the hind wings are without a closed anal cell because although this region is incompletely preserved in both, the vein closing the hind wing anal cell in other Siricidae is not detected where it should be visible if present (see Schiff et al. 2012, fig. A3.29). We cannot judge hamuli morphology by preservation.

Wedmann (1998, fig. 1) proposed the absence of the hind wing anal cell as a synapomorphy of (Eriotremex Benson 1943, Afrotremex Pasteels 1951, Tremex Jurine 1807); it is also absent in the female of Teredon (Schiff et al. 2012). This relationship is supported by the morphological phylogenetic analysis of Schiff et al. (2012, fig. C1.14), who recovered Eriotremex, Afrotremex, Tremex and Teredon as a clade.

A remarkable character of Eoteredon gen. nov. is the greatly broadened hind femora compared to the width of the hind tibia, broader than in any other Siricidae (AN pers. obs.; Konow 1905). In Teredon the hind femur is narrower than the maximum width of the hind tibia (Schiff et al. 2012, fig. C35.2).

\section{Paleobiogeography and paleoclimate of Eoteredon gen. nov.}

The great majority of modern Siricidae occupy boreal temperate forests from mid-latitudes north to the tree line and are mostly found at higher, cooler elevations in the southern parts of their range. This is a pattern seen in various insect taxa such as Panorpidae (Archibald et al. 2013) and Polystoechotidae (Archibald \& Makarkin 2006). For example, Sirotremex flammeus Smith 1988 is known from near Durango, Mexico at 2500 meters elevation (Schiff et al. 2012) and Sirex hispaniola Goulet (in Schiff et al. 2012) in the Cordillera Central of Hispaniola above 1000 meters.

A few taxa in the southern portion of their distribution do, however, inhabit hot, lowland climates, e.g., Afrotremex is only known from equatorial Africa (Uganda, Congo, Democratic Republic of Congo, Cameroon, Ghana: reviewed by Schiff et al. 2012), and Eriotremex species occur through east and southeast Asia in a variety of climates from Japan south to Vietnam, Indonesia, Malaysia, Papua New Guinea and Borneo (Smith 2010; Schiff et al. 2012; Taeger et al. 2018).

Teredon is one of these, known from La Habana Province of Cuba, the Dominican Republic, and Belize (Goulet et al. 2015), all south of the Tropic of Cancer in lowlands with megathermal mean annual temperatures (MAT). La Habana Province is rarely over 100 meters in elevation; its capital, Havana, has a MAT of $24.9^{\circ} \mathrm{C}$ (ClimateData.Org 2021). The Dominican Republic specimen is from the north coast town of Soúsa, which has an average temperature of $25^{\circ} \mathrm{C}$ (Climate-Data.Org 2021). The Belize specimen is from northern Belize at Lamanai Research Station, Orange Walk District $(17.74995,-88.65477)$, at about 22 meters elevation. The Orange Walk District has a mean annual temperature of $26.3^{\circ} \mathrm{C}$ (National Meteorological Service of Belize 2021).

Mesothermal to megathermal MAT values have been estimated for various Green River Formation sites using leaf margin analysis (Wilf 2000; Fricke \& Wing 2004; Archibald et al. 2011; Kester and Aase current research). However, these estimates may be low by taphonomic biases and their confidence intervals may be underestimated or are lacking (Little et al. 2010). The 18-inch Layer where Eoteredon gen. nov. was recovered was within the Early Eocene Climatic Optimum, an interval of the late Ypresian of increased atmospheric carbon and the highest sustained global MAT values of the Cenozoic (Zachos et al. 2008; Inglis et al. 2020). 

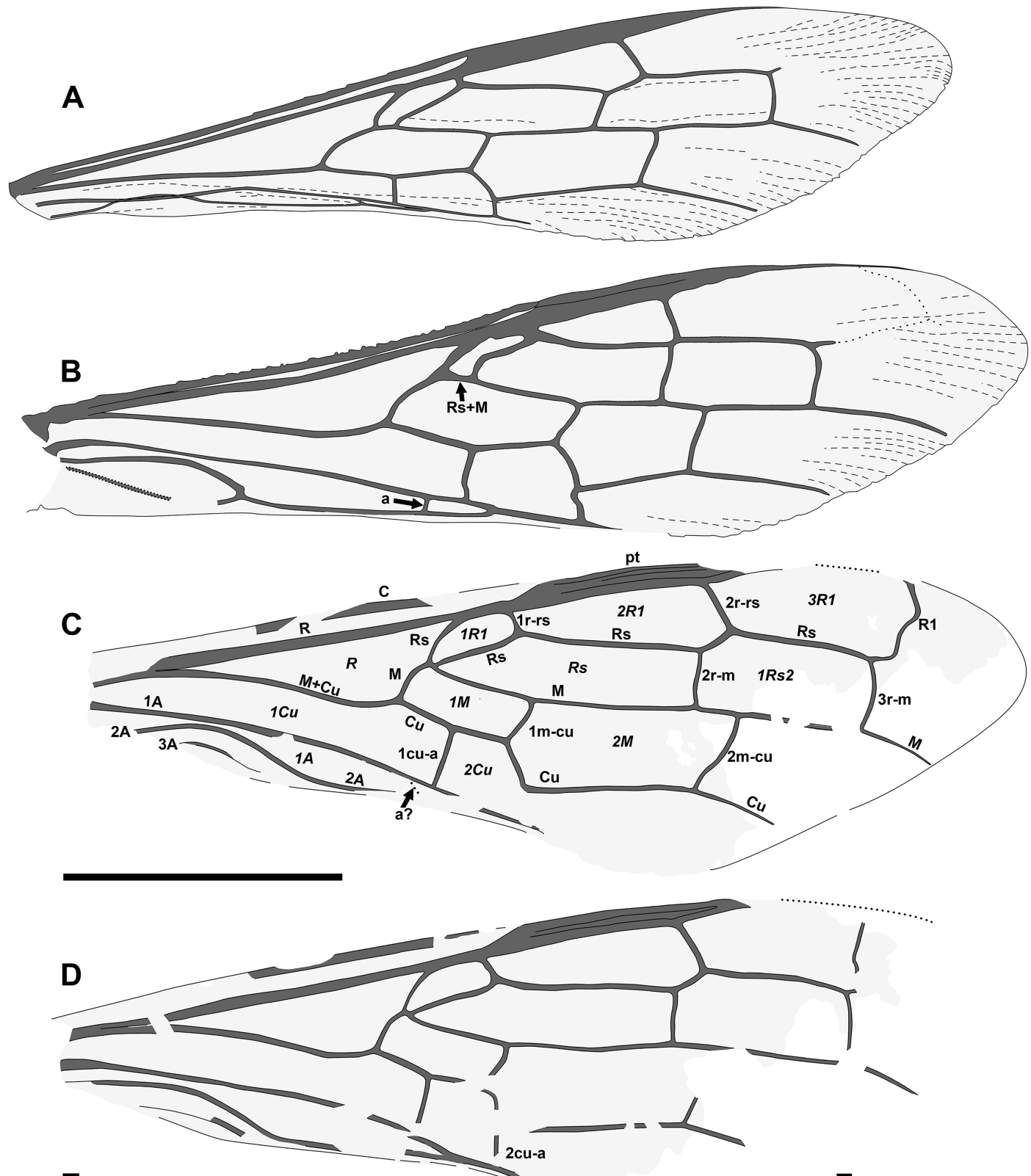

E
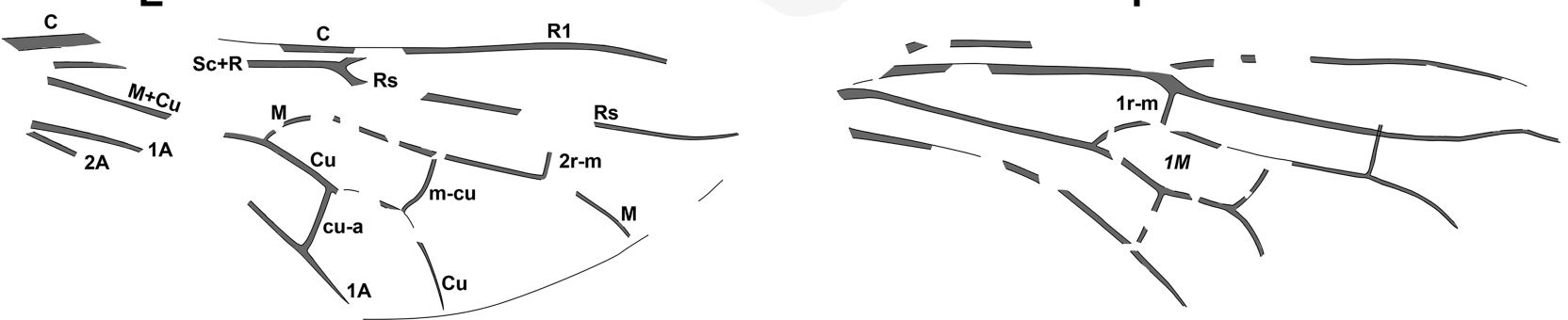

FIGURE 4. Drawings of wings of A, B, Teredon cubensis and C-F, Eoteredon lacoi gen. et sp. nov., holotype. A, T. cubensis male forewing, somewhat crushed in the basal posterior region. B, T. cubensis female forewing. C, right forewing of E. lacoi. D, left forewing of E. lacoi. E, E. lacoi female left hind wing. F, E. lacoi female right hind wing. Veins labelled in Roman font, cell names in italics. A, B re-drawn from Schiff et al. (2012, figs. C1.36, C34.5, no scale bars on originals). Scale bar $=5 \mathrm{~mm}$ (C-F). 
A siricid close to Eriotremex or Afrotremex is known from the Oligocene of Enspel, Germany, and a Tremex sp. from the Pliocene of Willerhausen, Germany (Wedmann 1998). Dispersal of members of the clade (Eriotremex, Afrotremex, Tremex, Teredon, Eoteredon gen. nov.) between North America and Eurasia could have been in either direction, possibly during the Late Cretaceous through Eocene by Holarctic land connections across the North Atlantic or Beringia (Brikiatis 2014); land connected the Caribbean region after the Middle Eocene (Iturralde-Vinent 2006). Members of the clade requiring higher MAT environments would have had to make a North Atlantic land bridge crossing during brief hyperthermal intervals (Archibald et al. 2011). Eoteredon gen. nov. went extinct sometime after the Ypresian and Teredon originated at an unknown time, today restricted to the tropical Caribbean region.

\section{Acknowledgements}

We thank Harold Ikerd of the Pollinating Insect-biology, Management, Systematics Research unit of the United States Department of Agriculture ("the Bee Lab") in Logan, Utah for photography; and Green River Stone Company under the leadership of Greg Laco for donating the holotype specimen to Fossil Butte National Monument. SBA thanks Rolf Mathewes (Simon Fraser University, Burnaby, BC, Canada) for support. We thank two anonymous reviewers for improvements to the manuscript.

Contributions to this paper including portions of text and design of Figures 1 and 2 are by Arvid Aase, a US government federal employee; they were completed as part of his official duties and as such are considered to be a US Government publication. Under provisions of the Copyright Act (17 USC Section 8), there is no copyright claimed on those portions of this work.

\section{References}

Archibald, S.B. \& Rasnitsyn, A.P. (2016) New early Eocene Siricomorpha (Hymenoptera: Symphyta: Pamphiliidae, Siricidae, Cephidae) from the Okanagan Highlands, western North America. The Canadian Entomologist, 148, 209-228. https://doi.org/10.4039/tce.2015.55

Archibald, S.B., Johnson, K.R., Mathewes, R.W. \& Greenwood, D.R. (2011) Intercontinental dispersal of giant thermophilic ants across the Arctic during early Eocene hyperthermals. Proceedings of the Royal Society of London, (B), 278, 3679-3686. https://doi.org/10.1098/rspb.2011.0729

Archibald, S.B., and Makarkin, V.N. (2006) Tertiary Giant Lacewings (Neuroptera: Polystoechotidae) revision and description of new taxa from western North America and Denmark. Journal of Systematic Paleontology, 4, 119-155, 307 (errata). https://doi.org/10.1017/S1477201906001817

Archibald, S.B., Mathewes, R.W., \& Greenwood, D.R. (2013) The Eocene apex of panorpoid scorpionfly family diversity. Journal of Paleontology, 87, 677-695. https://doi.org/10.1666/12-129

Benson, R.B. (1943) Studies in Siricidae, especially of Europe and southern Asia (Hymenoptera, Symphyta). Bulletin of Entomological Research, 34, 27-51. https://doi.org/10.1017/S0007485300023464

Billberg, G.J. (1820) Enumeratio Insectorum in Museo Gustav Johan Billberg. Typis Gadelianis, Stockholm, 138 pp. https://doi.org/10.5962/bhl.title.49763

Brikiatis, L. (2014) The De Geer, Thulean and Beringia routes: key concepts for understanding early Cenozoic biogeography. Journal of Biogeography, 41, 1036-1054. https://doi.org/10.1111/jbi.12310

Buchheim, P.H., Cushman, R.A. Jr. \& Biaggi, R.E. (2011) Stratigraphic revision of the Green River Formation in Fossil Basin, Wyoming: overfilled to underfilled lake evolution. Rocky Mountain Geology, 46, 165-181. https://doi.org/10.2113/gsrocky.46.2.165

Climate-Data.Org (2021) website: https://en.climate-data.org/north-america/dominican-republic/puerto-plata/sosua-25563/ (accessed 23 April 2021)

Cresson, E.T. (1865) On the Hymenoptera of Cuba. Proceedings of the Entomological Society of Philadelphia, 4, 1-4.

Fricke, H.C. \& Wing, S.L. (2004) Oxygen isotope and paleobotanical estimates of temperature and $\delta^{18} \mathrm{O}$-latitude gradients over North America during the early Eocene. American Journal of Science, 304, 612-635. https://doi.org/10.2475/ajs.304.7.612

Goulet, H., Smith, D.R., Smith, M.A. \& Fernandez-Triana, J. (2015) New country records for Teredon cubensis (Cresson) (Hymenoptera: Siricidae). Proceedings of the Entomological Society of Washington, 117, 522-524. 
https://doi.org/10.4289/0013-8797.117.4.522

Inglis, G.N., Bragg, F., Burls, N.J., Cramwinckel, M.J., Evans, D., Foster, G.L., Huber, M., Lunt, D.J., Siler, N., Steinig, S., Tierney, J.E., Wilkinson, R., Anagnostou, E., de Boer, A.M., Jones, T.D., Edgar, K.M., Hollis, C.J., Hutchinson, D.K. \& Pancost, R.D. (2020) Global mean surface temperature and climate sensitivity of the early Eocene Climatic Optimum (EECO), Paleocene-Eocene Thermal Maximum (PETM), and latest Paleocene. Climate of the Past, 16, $1953-1968$. https://doi.org/10.5194/cp-16-1953-2020

Iturralde-Vinent, M. (2006) Meso-Cenozoic Caribbean paleogeography: implications for the historical biogeography of the region. International Geology Review, 48, 791-827. https://doi.org/10.2747/0020-6814.48.9.791

Jouault, C., Pouillon, J.-M. \& Nel, A. (2020) The first fossil horntail wasp (Hymenoptera: Siricidae) from Lower Cretaceous Crato Formation in Brazil. Palaeoentomology, 3, 382-389. https://doi.org/10.11646/palaeoentomology.3.4.10

Jurine, L. (1807) Nouvelle méthode de classer les Hyménoptères et les Diptères. Vol. 4. Chez J.J. Paschoud, Genève et Paris, $319 \mathrm{pp}$. https://doi.org/10.5962/bhl.title.60886

Konow, F.W. (1905) Hymenoptera fam. Siricidae. Genera Insectorum, 28, 1-14.

Little, S.A, Kembel, S.W \& Wilf, P. (2010) Paleotemperature proxies from leaf fossils reinterpreted in light of evolutionary history. PLoS ONE, 5, e15161 https://doi.org/10.1371/journal.pone.0015161

Linnaeus, C. von (1758) Systema Naturae per regna tria naturae secundum classes, ordines, genera, species cum characteribus, differentiis, synonymis, locis. Ed. decima tertia, ad Editionem duodecimam reformata. Holmiae Direct, Laurentii Salvii, Typis Ioannis Thomae nob, De Trattnern, $823 \mathrm{pp}$. https://doi.org/10.5962/bhl.title.542

Luciani, V., D’Onofrio, R., Filippi, G. \& Moretti, S. (2020) Which was the habitat of early Eocene planktic foraminifer Chiloguembelina? Stable isotope paleobiology from the Atlantic Ocean and implication for paleoceanographic reconstructions. Global and Planetary Change, 191, 103216. https://doi.org/10.1016/j.gloplacha.2020.103216

National Meteorological Service of Belize (2021) Website. http://nms.gov.bz/

Nel, A. (1988) Redescription de Eosirex ligniticus Piton, 1940 (Hymenoptera, Symphyta, Siricidae). L'Entomologiste, 44, 287292.

Nel, A. (1991) Description et révision de trois “Siricidae” fossiles du Cénozoïque (Hymenoptera, Siricina, Vespina). Bulletin de la Société Entomologique de France, 96, 247-253. https://www.persee.fr/doc/bsef_0037-928x_1991_num_96_3_17719

Norton, E. (1869) Catalogue of the described Tenthredinidae and Uroceridae of North America. Transactions of the American Entomological Society, 2, 211-242 + 321-368. [https://www.jstor.org/stable/25076221] https://doi.org/10.2307/25076221

Pasteels, J. (1951) Sur quelques Tenthredinoidea africains. Bulletin et Annales de la Société Entomologique de Belgique, 887 , 195-205.

Rajchel, J. \& Uchman, A. (1998) Insect borings in Oligocene wood, Kliwa sandstones, Outer Carpathians, Poland. Annales Societatis Geologorum Poloniae, 68, 219-224.

Rasnitsyn, A.P. (1968) Novye Mezozojskie Pilil'shhiki (Hymenoptera, Symphyta). [New Mesozoic sawflies (Hymenoptera, Symphyta)]. In: Rodendorf, B.B. (Ed.) Jurskie Nasekomye Karatau [Jurassic insects of Karatau]. Nauka, Moscow, pp. 190-236. [In Russian].

Rasnitsyn, A.P. (1969) Origin and evolution of lower Hymenoptera. Trudy Paleontologicheskogo Instituta Akademii Nauk SSSR, 123, 1-196. [in Russian, with English translation by Amerind Co., New Delhi, India, 1979]

Riou, B. (1999) Descriptions de quelques insectes fossiles du Miocène supérieur de la Montagne d'Andance (Ardèche, France). Travaux de l'Ecole Pratique des Hautes Etudes, Biologie et Evolution des Insectes, 11-12, 123-133.

Schiff, N.M., Goulet, H., Smith, D.R., Boudreault, C., Wilson, A.D. \& Scheffler, B.E. (2012) Siricidae (Hymenoptera: Symphyta: Siricoidea) of the Western Hemisphere. Canadian Journal of Arthropod Identification, 21, 1-305. https://biologicalsurvey.ca/ejournal/sgsbws_21/sgsbws_21.html

Smith, D.R. (1988) A synopsis of the sawflies (Hymenoptera: Symphyta) of America south of the United States: Introduction, Xyelidae, Pamphiliidae, Cimbicidae, Diprionidae, Xiphydriidae, Siricidae, Orussidae, Cephidae. Systematic Entomology, 13, 205-261 https://doi.org/10.1111/j.1365-3113.1988.tb00242.x

Smith, D.R. (2010) The woodwasp genus Eriotremex (Hymenoptera: Siricidae), a review and a new species from Malaysia. Proceedings of the Entomological Society of Washington, 112, 423-438. https://doi.org/10.4289/0013-8797.112.3.423

Smith, M.E. \& Carroll, A.R. (2015) Introduction to the Green River Formation. In: Smith, M.E. \& Carroll, A.R. (Eds.), Stratigraphy and Paleolimnology of the Green River Formation, Western USA. Springer, New York, pp. 1-12. https://doi.org/10.1007/978-94-017-9906-5_1

Smith, M.E., Carroll, A.R. \& Singer, B. (2008) Synoptic reconstruction of a major ancient lake system: Eocene Green River 
Formation, western United States. Geological Society of America Bulletin, 120, 54-84.

https://doi.org/10.1130/B26073.1

Smith, M.E., Chamberlain, K.R., Singer, B.S. \& Carroll, A.R. (2010) Eocene clocks agree: Coeval ${ }^{40} \mathrm{Ar} /{ }^{39} \mathrm{Ar}$, U-Pb, and astronomical ages from the Green River Formation. Geology, 38, 527-530. https://doi.org/10.1130/G30630.1

Taeger, A., Liston, A.D., Prous, M., Groll, E.K., Gehroldt, T. \& Blank, S.M. (2018) ECatSym - Electronic World Catalog of Symphyta (Insecta, Hymenoptera). Program version 5.0 (19 Dec 2018). Data version 40. 23 September 2018. Senckenberg Deutsches Entomologisches Institut (SDEI), Müncheberg. https://sdei.de/ecatsym/ (accessed 29 December 2020)

Wedmann, S. (1998) First records of fossil tremecine hymenopterans. Palaeontology, 41, 929-938. https://www.palass.org/publications/palaeontology-journal/archive/41/5/article_pp929-938

Wedmann, S., Pouillon, J.-M. \& Nel, A. (2014) New Palaeogene horntail wasps (Hymenoptera, Siricidae) and a discussion of their fossil record. Zootaxa, 3869 (1), 33-43. https://doi.org/10.11646/zootaxa.3869.1.3

Wilf, P. (2000) Late Paleocene-early Eocene climate changes in southwestern Wyoming: paleobotanical analysis. Geological Society of America Bulletin, 112, 292-307. https://doi.org/10.1130/0016-7606(2000)112<292:LPECCI $>2.0 . C O ; 2$

Wolfe, J.A. (1975) Some aspects of plant geography of the Northern Hemisphere during the Late Cretaceous and Tertiary. Annals of the Missouri Botanical Garden, 62, 264-279. https://doi.org/10.2307/2395198

Zachos, J.C., Dickens, G.R. \& Zeebe, R.E. (2008) An early Cenozoic perspective on greenhouse warming and carbon-cycle dynamics. Nature, 451, 279-283.

https://doi.org/10.1038/nature06588 